\title{
Discourse, Strategy, and Practice of Urban Resilience against Flooding
}

\author{
Yu-Shou Su ${ }^{1 \& 2}$ \\ ${ }^{1}$ Inspector, National Development Council, Taiwan (R.O.C.) \\ ${ }^{2}$ Fellow, Penn Institute for Urban Research (Penn IUR), University of Pennsylvania, United States \\ Correspondence: Yu-Shou Su, National Development Council, 3F., No. 3 Baoqing Road, Taipei City 10020, Taiwan \\ (R.O.C.). Tel: 886-2-2316-5816.
}

\author{
Received: January 13, 2016 Accepted: January 28, 2016 Online Published: February 1, 2016 \\ doi:10.11114/bms.v2i1.1348 URL: http://dx.doi.org/10.11114/bms.v2i1.1348
}

\begin{abstract}
Resilience discourse is shifting the very meaning of "resilience" from "bouncing back" to "bouncing forward" in the twenty-first century. International policies have provoked cities to play a proactive role in applying land-use and environmental planning strategies for disaster resilience. Strategies of urban flood resilience include prevention, accommodation, fortification, protection, retreat, and green infrastructure. In general, four models of resilience against flooding are primarily adopted: the structure model, the non-structure model, the land-use and environmental planning model, and the retreat planning model. Results indicate that planning more space for the river, wetland planning, polder and retention areas, and permeable surface design do matter in reducing flood risks. Additionally, urban growth management, directing developments and populations away from floodplains, could reduce flood risks and damages. Finally, in retreat model, urban resilience stresses retreat and evacuation to reduce flood damages. Retreat strategies and alternatives, such as property buyouts, relocations, new towns for accommodations, and land swaps for less risky areas, could be applied in helping to achieve urban flood resilience.
\end{abstract}

Keywords: urban resilience, resilience planning, flood prevention, sustainability

\section{Introduction}

The number of climate-related disasters, floods and storms, has soared significantly around the world since the 1980s. Urban resilience is gaining influence. Strengthening resilience helps to achieve sustainability. Diverse concepts of resilience, including equilibrium resilience, adaptive resilience, evolutionary resilience, and social-ecological resilience, were proposed in the past three decades. However, in the spatial planning field, urban resilience is still quite a new topic with lack of practice and implementation. Some questions remain uncertain. What is resilience planning? Can resilience be planned? How is resilience implemented? How is resilience measured? Additionally, literature reviews indicate the lack of articles regarding urban resilience and resilience planning. This article fills the gap regrading urban resilience planning. First, it analyzes the discourse, international policy, and institution to understand the context and content of urban resilience. Second, this article discusses major strategies of urban resilience planning. Third, it explains four models being used to encourage urban flood resilience, including the engineering/structure model, the non-engineering/non-structure model, the land-use and environmental planning model, and the retreat planning model. These four models of urban flood resilience are not independently adopted for policies. On the contrary, the combination of these four models helps to achieve urban resilience against flooding.

\section{Discourse, Policy, and Institution of Urban Resilience}

Resilience originally meant the ability of a system to return to its original condition after a disturbance, which was defined as engineering resilience or equilibrium resilience (Holling 1973). However, the resilience discourse is shifting from equilibrium resilience to adaptive, evolutionary, and social-ecological resilience. This results in shifting the very meaning of "resilience" from "bouncing back" to "bouncing forward" in the twenty-first century. In other words, engineering or equilibrium resilience, focusing on return time, recovery, and bouncing back, has shifted to evolutionary, adaptive, and social-ecological resilience, emphasizing bouncing forward and robust function with adaptive capacity and self-organization to disturbances. Adaptive resilience for "bouncing forward" has become a core value of resilience. The more adaptive, persistent, and transformable their system, the more resilient a city is. "Urban resilience is a city that is adjustable, adaptive, and flexible to evolve in the face of uncertainty or disasters. Enhanced resilience also allows 
better anticipation of disasters and better planning to reduce disaster losses" (The National Academy of Sciences 2012). Although diverse concepts of resilience were proposed after the 1970s, some questions in the planning field remain uncertain. What is resilience planning? Can resilience be planned? How is resilience implemented? How is resilience measured? Generally, resilience planning is still quite a new topic with lack of practice and implementation. In city planning, resilience was not an emphasis until the sustainable development movement and devastating natural disasters occurred in the twenty-first century. The concept of sustainability helps resilience planning, but sustainability and resilience are different. Sustainable development mainly focuses on equity and efficiency of resource use. However, resilience planning concentrates mostly on the adaptive strategies after disasters or preventive policies for disaster risk reduction. Although sustainability and resilience are different in meaning, scope, and practice, they have a relationship of integrative dependence. As Yuzva and Zimmermann (2012) stress "a sustainable city must be a resilient city". Riasi and Pourmiri (2016) studied the relationship between sustainability, urban resilience, and tourism industry and found that cities with strong plans for urban resilience are more successful in achieving sustainability. Many other studies also found a similar relationship between resilience and sustainability (Amiri Aghdaie et al. 2012; Fiskel 2006; Milman and Short 2008; Riasi and Amiri Aghdaie 2013; Riasi and Pourmiri 2015; Rosic et al. 2009). Therefore, strengthening urban resilience helps to achieve sustainability.

Regarding urban resilience, few books and articles have promoted resilience planning since 2000. For instance, Vale and Campanella (2005), The Resilient City, explain how modern cities recover from disasters, particularly after devastating earthquakes and city fires; Birch and Wachter (2006), Rebuilding Urban Places after Disaster, written after Hurricane Katrina, describes how to rebuild, prepare for disaster risk reduction, and make cities less vulnerable by different levels of government in partnership with the private sector and public will. Regarding journal articles in planning, the Journal of the American Planning Association (JAPA) from 1999 to 2009 has published only one article with urban resilience in the title: Campanella (2006) "Urban Resilience and the Recovery of New Orleans". This article argues that urban resilience involves much more than rebuilding. No article with a title pertaining to urban resilience and resilience planning of the Journal of Planning Education and Research (JPER) in 1995-2014. However, there are 10 articles with a title related to rebuilding, post-disaster planning, and natural hazard mitigation planning during the past twenty years, mostly published after 2005. In the JAPA, there are 6 articles with a title of natural disaster, rebuilding, resilience, or recovery. Therefore, after devastating Hurricane Katrina in 2005, there are more articles discussing urban resilience. For example, there are 2 out of 9 articles in the JAPA's Spring 2006 discussing urban resilience. A new journal focused on resilience was released in 2010, the International Journal of Disaster Resilience in the Built Environment (IJDRBE). The IJDRBE's Issue 1 of 2013: "Special Issue: Making Cities Resilient". More articles discuss rebuilding experiences and disaster risk reduction, mainly developing countries' case studies.

International policies regarding resilience can help to understand the concept of urban resilience planning. Notable is the United Nations International Strategy for Disaster Reduction (UNISDR). The UNISDR indicates that "a resilient city can be planned by a more proactive role in applying land-use planning in natural disasters and hazard mitigation". In general, there are three major international policies for urban resilience: 1. Framework for Action 2005-2015: Building the Resilience of Nations and Communities to Disasters (known as HFA) and the Post-2015 Framework for Disaster Risk Reduction (known as HFA2); 2. Sustainable Development Goals (SDGs): the eleventh goal is to make cities and human settlements inclusive, safe, resilient and sustainable; and 3. Intergovernmental Panel on Climate Change (IPCC) report on Climate Change 2014: Impacts, Adaptation, and Vulnerability. In sum, the HFA, SDGs, and IPCC have provoked cities to play a proactive role in applying land-use planning strategies in disaster risk reduction (see Table 1). Mitchell et al. (2014) argue that "integrating these three frameworks of HFA, SDGs, and IPCC will provide a unique opportunity to deliver a coherent strategy and implementation plan to reduce disaster risk". They also propose a global target of reducing 50\% of deaths and 20\% of economic losses from all disasters by 2030 (Mitchell et al. 2014). 
Table 1. International policies regarding urban resilience

\begin{tabular}{|c|c|c|}
\hline International policies & $\begin{array}{l}\text { Framework for Action } \\
\text { 2005-2015: Building the } \\
\text { Resilience of Nations and } \\
\text { Communities to Disasters } \\
(H F A)\end{array}$ & $\begin{array}{l}\text { United Nations' Sustainable Intergovernmental Panel on } \\
\text { Development Goals (SDGs) Climate Change (IPCC) }\end{array}$ \\
\hline Goals & $\begin{array}{l}2005 \\
\text { - Promote a strategic and } \\
\text { systematic approach to } \\
\text { reduce vulnerabilities and } \\
\text { risks to hazards } \\
\text {-Involve community-level } \\
\text { participation } \\
\text { - Target the most vulnerable } \\
\text { populations, } \\
\text { - Integrate climate change } \\
\text { adaptation, development } \\
\text { and disaster risk } \\
\text { reduction, } \\
\text { - Strengthen } \\
\text { capacity-building of } \\
\text { financing, risk assessment, } \\
\text { and preparedness }\end{array}$ & 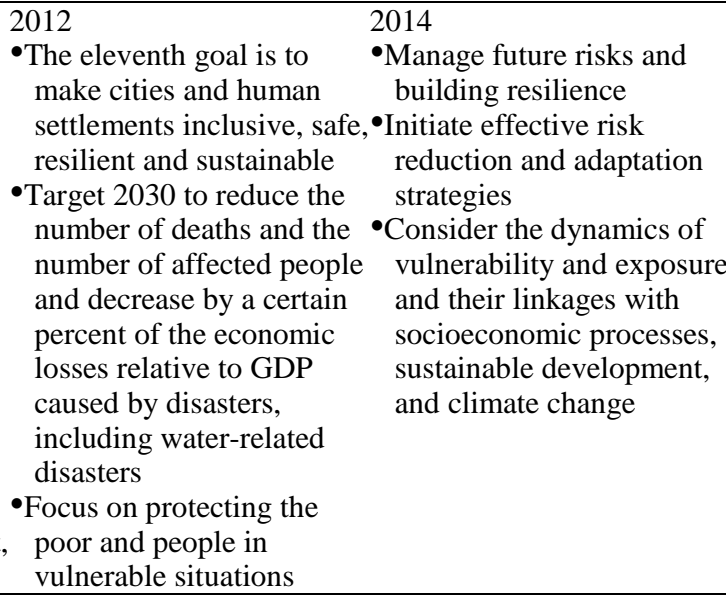 \\
\hline
\end{tabular}

The HFA puts emphasis on the importance of city planning to achieve resilience and reduce risks. The HFA's "Making Cities Resilient Campaign", launched in 2010, has provoked local governments to play a role in urban resilience. The HFA2 suggests that urban resilience focuses on community-level involvement, targeting the most vulnerable populations, integrating climate change adaptation, strengthening capacity-building of financing, risk assessment, and preparedness, and promoting political will and leadership. Additionally, the UNISDR recommends some steps to make cities resilient: 1. create and fund well-defined coordinated organizational structures; 2. prepare risk assessments, develop and enforce risk-compliant building codes and land-use planning tools; 3 . strengthen critical infrastructure and upgrade key facilities; 4. protect ecosystems and natural buffers; 5. test early-warning systems and emergency management capacities; 6. sponsor education and training programs on disaster risk reduction (UNISDR 2013). At the end of 2014, the United Nations released two reports: Post-2015 Framework for Disaster Risk Reduction: Zero Draft (known as Zero Draft) and Suggested Elements for the Post-2015 Framework for Disaster Risk Reduction. The two reports provide suggestions for local governments to implement a resilience plan, including: periodically estimate the probability of disaster risks to the population and to economic and fiscal assets; ensure that national and local plans prevent the creation of new risks, reduce existing risks and strengthen resilience; guide the public sector in addressing disaster risk; regulate and provide incentives for actions by households, communities, businesses and individuals; review existing financial and fiscal instruments; and stimulate the development of disaster risk management (United Nations 2014). In March 2015, the Third United Nations World Conference on Disaster Risk Reduction was held in Sendai, Japan. This conference stresses that disaster risk reduction inherently involves forward planning. Investments in disaster risk reduction and urban resilience can advance both sustainable development and climate action. This conference also stresses that help must be given the poorest and most vulnerable people and countries to manage disaster risk. The Implementation of the Sendai Framework for Disaster Risk Reduction over the next 15 years will require strong commitment and political leadership. Several targets are to be achieved in this framework: a reduction of disaster mortality, affected people, economic losses, and critical infrastructure; an increase in the number of countries with national and local disaster risk reduction strategies by 2020; enhanced international cooperation; and increased access to multi-hazard early warning systems and disaster risk information and assessments (UNISDR 2015).

The SDGs' eleventh goal is to make cities and human settlements inclusive, safe, resilient and sustainable. This goal is aimed to significantly reduce deaths, affected people, and economic losses caused by flood-related disasters by 2030 . The goal concentrates on protecting the poor and people in vulnerable situations. Additionally, this goal aims to increase the number of cities and human settlements adopting and implementing integrated policies towards resilience to disasters (United Nations 2013). The IPCC's report on Climate Change 2014: Impacts, Adaptation, and Vulnerability considers how the impact and risk related to climate change can be reduced through adaptation and mitigation. Effective risk reduction and adaptation strategies must consider the dynamics of vulnerability and exposure. This report indicates that some low-lying developing countries and small island states are expected to face very severe impacts. These low-lying areas must take actions to address risks and impacts.

In addition to international policies, there are international institutions promoting urban resilience: the United Nations' International Strategy for Disaster Reduction (UNISDR), the World Bank's Global Facility for Disaster Reduction and 
Recovery (GFDRR), the OECD's Risk Management Division under the Directorate for Public Governance and Territorial Development, the Centre for Research on the Epidemiology of Disasters (CRED), the European Flood Directive (FD), Global Disaster Alert and Coordination System (GDACS), Asian Disaster Reduction Center (ADRC), and Asian Disaster Preparedness Center (ADPC), presented in Table 2. The World Bank mainly concentrates on the Asian nations' case studies. The World Bank (2013) report Building Urban Resilience: Principles, Tools, and Practice stresses that resilience planning needs to be the focus for cities. This report indicates that increasing population growth, urbanization and property development in urban vulnerable areas will be the major factor of increased damages and losses from disasters in the next decades. In East Asia, the urban population is expected to double between 1994 and 2025 (Jha and Brecht 2011). Most cities, with their concentration of assets, located along the coastline, in floodplains, or along seismic rifts, are vulnerable to disasters. Rapid and unplanned urbanization in combination with poorly constructed settlements and degraded ecosystems put more people and more assets in harm's way (The World Bank 2013). Building urban resilience relies on investment decisions that prioritize spending on activities that offer alternatives that perform well in different scenarios. The goal is also to formulate a strategy in which flexible and low-regret measures can be cost-effective even when risks are uncertain. Integrating risk-based approaches into urban governance and planning processes do matter in implementing policies of urban resilience. 
Table 2. International institutions and programs regarding urban resilience and disaster risk reduction

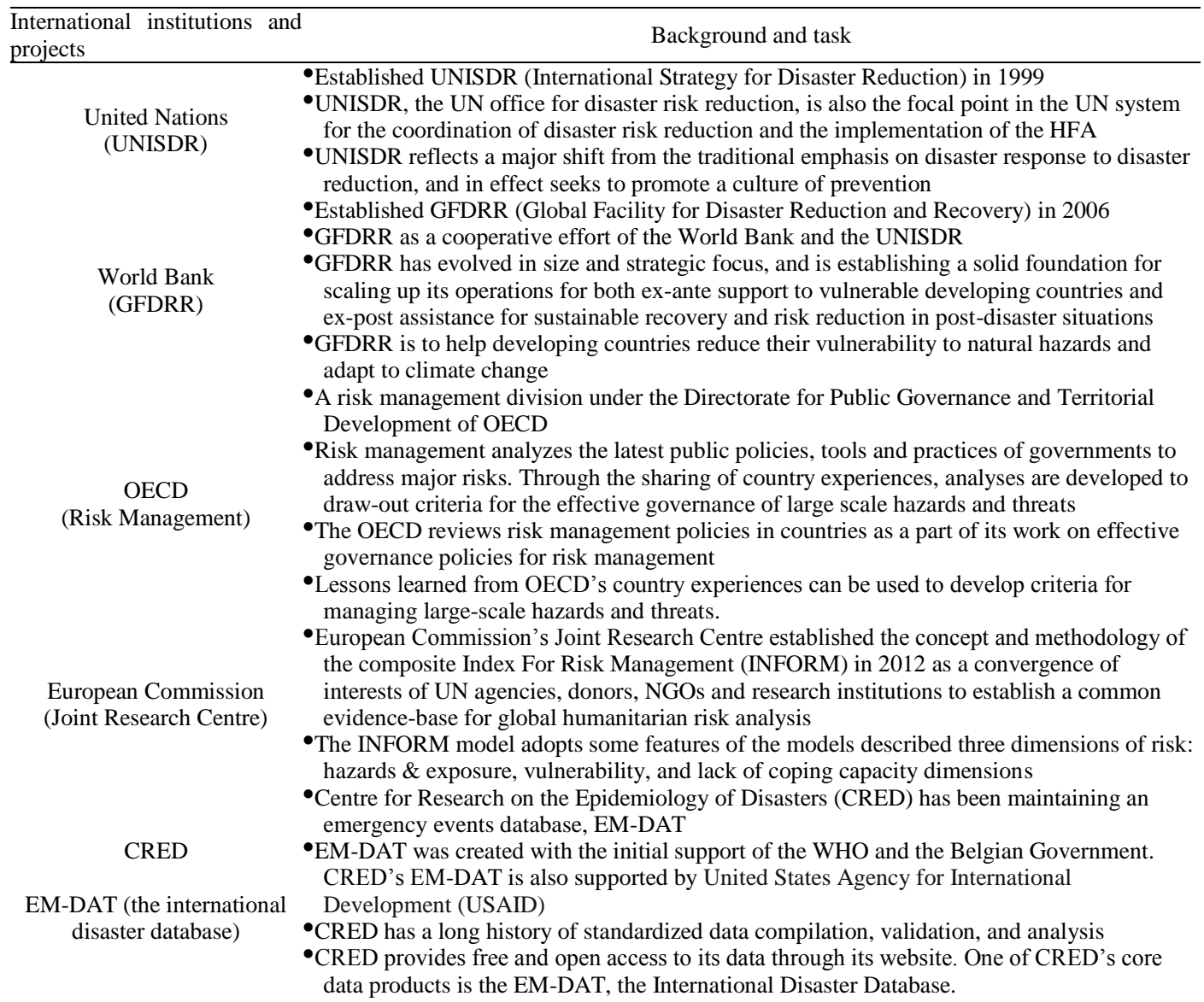

-The European Flood Directive (FD) was proposed by the European Commission in 2006 to reduce and manage the flood risk.

European Flood Directive ${ }^{\bullet}$ EU's $7^{\text {th }}$ Framework Program for Research and Technological Development (FP7) project: a

(FD) and EU's CORFU collaborative research on flood resilience in urban areas (CORFU), ongoing case studies project include: Barcelona, Beijing, Dhaka, Hamburg, Mumbai, Nice, Taipei, Incheon, and Seoul

- $\mathrm{CORFU}$ is to map the potential floods, vulnerability of the assets and humans at risk, and to take adequate and coordinated measures to reduce flood risk

$\bullet$ FRC has enabled responsible public authorities in eight cities in North West Europe to better cope with floods in urban areas

Flood Resilience City (FRC, • Ongoing eight case studies, including: Bradford, Brussels and Leuven, Dublin, Mainz, EU-funded project)

Nijmegen, Orleans, and Paris

•FRC is assessing the likelihood and consequences of current and future flooding, and the costs and benefits of different treatment options

- Global Disaster Alert and Coordination System (GDACS) is a cooperation framework under the United Nations umbrella Global Disaster Alert and
Coordination System $\quad$ GDACS includes disaster managers and disaster information systems worldwide and aims at (GDACS) filling the information and coordination gap in the first phase after major disasters

-GDACS provides real-time access to web - based disaster information systems and related coordination tools

-Promote a strategic and systematic approach to reduce vulnerabilities and risks to hazardsAsian Disaster Preparedness Center (ADPC) was established in Bangkok, Thailand, in 1986

Asian Disaster Preparedness

-ADPC has country offices in Bangladesh, Lao PDR and Myanmar. ADPC deploys disaster Center (ADPC) risk management (DRM) information and systems to reduce local, national and regional risk across Asia-Pacific.

-ADPC has a team of approximately hundred experts from 19 countries. ADPC creates a department of Resilient Cities and Urban Risk Management to assists cities and communities in managing and mitigating urban disaster risks.

- Asian Disaster Reduction Center (ADRC) was established in Kobe, Hyogo prefecture, in 1998 , in response to the 1995 Kobe earthquake.

Asian Disaster Reduction $\quad$ ADRC is to promote international cooperation and collaboration for the reduction of natural Center (ADRC) disasters in the Asian region. ADRC has 30 member countries and works to enhance disaster resilience. ADRC also addresses this issue from a global perspective in cooperation with a variety of United Nations' agencies including UNISDR. 
In Europe, two projects regarding urban flood resilience are underway: the EU's Collaborative Research on Flood Resilience in Urban Areas (CORFU) and Flood Resilience City (FRC). The CORFU project aims to map the potential floods, vulnerability of the assets and humans at risk, and to take adequate and coordinated measures to reduce flood risk. CORFU has ongoing case studies in Asia and Europe, including in Barcelona (Spain), Beijing (China), Dhaka (Bangladesh), Hamburg (Germany), Mumbai (India), Nice (France), Taipei (Taiwan), Incheon (South Korea), and Seoul (South Korea). The FRC project is to assess the likelihood and consequences of current and future flooding, and the costs and benefits of different treatment options. There are eight ongoing case studies in Europe: Bradford (UK), Brussels and Leuven (Belgium), Dublin (Ireland), Mainz (Germany), Nijmegen (Netherlands), Orleans (France), Paris (France). In Asia, there are two disaster reduction centers, the Asian Disaster Preparedness Center (ADPC) established in Bangkok in 1986, and the Asian Disaster Reduction Center (ADRC), which was established in Kobe in response to the 1995 Kobe earthquake in order to promote international cooperation and collaboration for disaster risk reduction among 30 Asian countries. These international institutions have promoted the research and policy implementation of urban resilience in the world.

\section{Strategies of Urban Resilience Planning against Flooding}

The goal of urban resilience planning is to reduce risks through planning. Generally, two types of strategy are: traditional engineering strategy and land-use planning strategy. Deyle and Butler (2013) identify 3 strategies for urban resilience on coastal hazards reduction: protest, accommodate, and avoid/ retreat (see Table 3). The Association of Bay Area Governments (2013) also describes some tools for resilience planning, including: general plans and specific plans; zoning tools such as overlay districts, nonconforming use regulations, special use permits; buyouts and financial incentives for where to build or not build. Olshansky (2009) observes that acquisition of flood-prone properties and permanent conversion of those properties to open space has become a leading federal strategy for solving serious flood problems since the 1993 floods in the Midwest of the U.SA. Further, Burby et al. (2006) point out that resilience planning includes "preventive, protection, and emergency policies". They indicate a preventive policy to limit the exposure of new development; property protection policy to retrofit buildings; and emergency services policy to reduce damages (Burby et al. 2006). They emphasize that urban planners should play a key role in preventive policies to reduce the exposure to disasters. However, with these diverse strategies of prevention, protection, and retreat, the main problem is that local governments often put a low priority on taking action unless the higher government mandates it. Because of the pro-growth and pro-development of local governments, resilient planning to reduce disaster risk is often ignored. For instance, in the U.S.A., local governments are not likely to pursue such measures vigorously without being forced to do so through mandates imposed by state governments (Burby et al. 2006). However, some state governments incentivize municipal scenario planning processes for urban resilience. Take New York State for instance, the NYS 2100 Commission (2012) suggests that the state can incentivize municipal scenario planning processes for evaluating risk to human, environmental, and economic assets from coastal storms and sea-level rise. Hence, resilience policies also need a top-down method as well as mandates and support from higher levels of government. 
Table 3. The content and strategy of resilience planning

\begin{tabular}{|c|c|}
\hline Resilience planning & Content and strategy \\
\hline Core ideas & $\begin{array}{l}\text { - An alternative plan format, a policy plan, rather a conventional plan } \\
\text { - Risk-based land use planning, instead of traditional development ignoring the } \\
\text { hazard characteristics of land }\end{array}$ \\
\hline \multirow[t]{2}{*}{ Scope } & $\begin{array}{l}\text { A regional approach for resilience planning; Long-term regional resilience } \\
\text { strategies must be developed }\end{array}$ \\
\hline & $\begin{array}{l}\text {-Integrating risk-based land use planning approach into urban governance and } \\
\text { process }\end{array}$ \\
\hline Planning process & $\begin{array}{l}\text {-Scenario planning process: providing the information, selecting complementary } \\
\text { land use and hazard-mitigation measures, and formalizing a long-term adaptation } \\
\text { strategy to effectively manage impacts }\end{array}$ \\
\hline \multirow[t]{2}{*}{ Prevention strategy } & $\begin{array}{l}\text { Preventive policies and actions, such as conservation zoning, to limit the exposure } \\
\text { of new development to losses from hazards }\end{array}$ \\
\hline & •Elevate structures \\
\hline \multirow[t]{3}{*}{ Accommodation strategy } & •Erosion-based setback \\
\hline & $\bullet$ Room for the water \\
\hline & •Shore armoring; beach nourishment \\
\hline \multirow[t]{2}{*}{ Protection strategy } & $\begin{array}{l}\text { - Property protection policies and actions, such as building standards and assistance } \\
\text { to property to owners to retrofit buildings to increase their resilience to hazards } \\
\text { - Structural protection policies and actions such as flood control works to provide } \\
\text { area-wide protection from hazards }\end{array}$ \\
\hline & -Prohibit development plus transfer of development rights \\
\hline \multirow{3}{*}{ Retreat/avoid strategy } & -Prohibit development plus acquisition \\
\hline & $\begin{array}{l}\text {-Post-disaster down-zoning planning with a tool of transfer of development rights } \\
\text {-Post-disaster plus acquisition }\end{array}$ \\
\hline & $\begin{array}{l}\text {-Rolling easements, initiated by U.S.A.'s EPA Climate Ready Estuaries Program, } \\
\text { which allow nature to take its course }\end{array}$ \\
\hline \multirow{2}{*}{$\begin{array}{l}\text { Green infrastructure } \\
\text { strategy }\end{array}$} & - A broader adoption of green infrastructure can minimize local problems with \\
\hline & $\begin{array}{l}\text {-Acquisition of flood-prone properties and permanent conversion of those } \\
\text { properties to open space. }\end{array}$ \\
\hline
\end{tabular}

In addition to resilience planning policies with cooperation among different levels of governments, a regional approach and integration is needed for urban resilience. Different cases show the importance. In New Orleans' experience, Birch and Wachter (2006) argue for a multidisciplinary approach for rebuilding after Hurricane Katrina. They point out that "the absence of an integrated approach has resulted in the pattern of ever increasing disasters and the need for cooperation across multiple levels of government". The Association of Bay Area Governments (ABAG 2013) also observes that there is no regional coordinating body currently in operation to facilitate decision-making in the aftermath of a major disaster. The ABAG indicates that "regional governance structures for coordination are well-established for disaster response". Hence, the ABAG created the Regional Resilience Initiative to build resilience through collaborative planning and jurisdictional collaboration (Association of Bay Area Governments 2013). In New York's rebuilding after Hurricane Sandy, the Hurricane Sandy Rebuilding Task Force (2013) stressed "the long-term plan for rebuilding is ensuring a regionally coordinated resilient approach to infrastructure investment because natural disasters do not respect political boundaries". Thus, rebuilding plans cannot be limited by jurisdictional boundary. Klinenberg and Ovink (2013) note this in the project Rebuild by Design which encourages plans on the regional scale, rather than the municipal or state level because many of the risks related to extreme weather events require cooperating across political boundaries.

\section{Four Models of Urban Resilience against Flooding}

The number of climate-related disasters, floods and storms, has soared significantly around the world since the 1980s (UNISDR 2013). As Kunreuther and Michel-Kerjan (2009) indicate, the $21^{\text {st }}$ century has been termed as "at war with the weather". Floods become more frequent and severely damaging because of rapid urbanization and extreme weather conditions. In both developing and developed countries, urbanization is causing change to the natural environment and threatens urban resilience. The urban poor live in more environmentally vulnerable areas in the developing countries (The World Bank 2001; 2013; Sinh et al. 2012). Urbanization in the developed countries has brought higher vulnerability and damage from flooding. In general, several models and practices being used to encourage urban flood resilience are: the engineering/structure model, the non-engineering/non-structure model, the land-use and environmental planning model, and the retreat planning model.

\subsection{Engineering/Structure Model}

Most countries adopted the engineering/structure model to reduce flood risk during the past century. This includes building costly dikes, dams, storm-surge barriers and dunes. In the United States, flood risk reduction has been dominated by the engineering strategy since the Mississippi River flooded in 1927. The Flood Control Act of 1930 
supported national structural flood control works (Brody et al. 2007, 2009). It is estimated that the U.S. Army Corps of Engineers (USACE) has spent more than $\$ 100$ billion for structural projects since the 1940s (Stein et al. 2000). An annual average of approximately $\$ 2$ billion was spent on flood control structures. However, these costly structural flood control projects often bring a false sense of security and result in encouraging new developments in and around floodplains. Once a flood event exceeds the capacity of the structure, it causes significant damage and economic loss. For instance, after the Galveston Hurricane of 1900, the city of Galveston, Texas built a seawall, 3 miles long and 17 feet high in 1902 to resist storm surges up to 15 feet high. However, seawalls cannot guarantee safety from a future storm. In 2008 Hurricane Ike's storm surge and large waves came over the seawall in Galveston. Severe losses occurred. Approximately $75 \%$ of all homes in Galveston were damaged or destroyed. Another example was the Great Mississippi Flood of 1927 where the flood proved that levee-dependence was an incontrovertibly failure. Prior to the flood, the Mississippi River Commission held the position that levees were the appropriate strategies for preventing floods. Powers (2006) describes that the 1927 flood altered the underlying theory regarding humanity's relationship with nature from one of domination to one of accommodation. Additionally, the Great Flood of 1993 tore through more than a thousand levees, causing almost $\$ 20$ billion of damage. In general, the average annual flood damage in the United States was estimated to have climbed steadily to $\$ 4$ billion (Stein et al. 2000). The USACE's annual \$2 billion investment on flood control structures can not reduce the increased annual flood damage of $\$ 4$ billion. In other words, although nationwide structural projects for controlling water were completed in the United States, urban flood resilience has not yet been achieved.

A similar situation occurred in the Netherlands, a nation with $65 \%$ of GDP produced below sea level. The well-known flood protection system, 53 dike rings, along the main rivers and coastal areas is the highest standard of flood protection facilities in the world. For example, Randstad, the economic heart of the Netherlands, is designed to resist a storm that is estimated to occur once in every 10,000 years (a probability of $0.01 \%$ annually). However, Wiering and Immink (2005) argue that the engineering strategy to reduce flood risk creates a "flood control paradox". The paradox is that strengthening dikes encourages more intensive land use. After a flood, dikes will be strengthened again. Then, higher density of land development occurs. Another flood will occur, and damages will be much more serious. This "flood control paradox" actually is a vicious cycle, and the measures to reinforce the dikes do not take away the cause of the problem, but create new risks (Wiering and Immink 2005). The Netherlands' dike ring protection structures were built with the highest standard after the devastating flood of 1953. However, severe floods still devastate Netherlands, such as the floods of 1993 and 1995. This explains why the highest level of flood protection system in the Netherlands can not guarantee absolute safety (Kolen et al. 2010).

In the United Kingdom, engineering structures to reduce flood risks are subsidized by central government, and continue to be the primary flood mitigation strategy (Penning-Rowsell and Handmer 1988). The costly facilities and repeated floods have made governments rethink the urban flood resilience policy. Studies indicate that "more money for flood defense would not be a permanent solution in the United Kingdom" (Howe and White 2010). The costly engineering structures can not guarantee safety or reduce flood damages efficiently and effectively. For instance, many flooding problems continue to threaten London after the completion of the Thames Barrier in 1982, the world's largest movable flood barriers. According to the Great London Authority (2002), the Thames tidal floodplain would have a $0.1 \%$ annual risk of flooding (a probability of $0.1 \%$ annually, or a flood in every 1,000 years), which amounts to a flood risk to property at a value of approximately $\$ 120$ billion. After numerous flood defense facilities in the U.K., floods occur in different locations, shifting the flood waters downstream (Howe and White 2010). Hence, flooding does not stop, but changes locations. In addition, the damage is worse when the defenses are eventually breached.

\subsection{Non-engineering/non-structure Model}

There are two types of non-structural model for urban flood resilience: the financial strategy and the planning strategy. The financial strategy includes rental incentives and insurance incentives. An example in Asia is Mumbai's rent control policy resulting in the lack of proper housing maintenance and severe damages from flooding. Stecko and Barber (2007) indicate that "many apartment buildings are subject to rent control which prohibits landlords from increasing rents in Mumbai. The rent control has constrained the willingness and ability of landlords to maintain rental accommodations, leading to inadequate housing". More and more buildings are dilapidated and crumbling due to the lack of proper maintenance (Stecko and Barber 2007). When a natural disaster occurs, the damage is severe. Thus, providing a financial incentive for landlords to increase rental in Mumbai would improve building maintenance and strengthen urban flood resilience. The financial incentive could also allow landlords to spend part of rent income for purchasing flood insurance.

Another financial strategy is flood insurance. Among flood insurance programs, the National Flood Insurance Program (NFIP) is most widely implemented in the United States and has been adopted by other countries. The NFIP was established in 1968 under the Federal Emergency Management Agency (FEMA) as an attempt to reduce flood losses. 
The NFIP provides insurance to those living in vulnerable areas as long as local jurisdictions adopt some minimum level of protection. FEMA creates the community's flood map and the flood insurance rate map (FIRM) to evaluate potential flood risk. In addition, FEMA's community rating system (CRS), adopted in the early 1990's, encourages communities to go beyond the NFIP's minimum standards for floodplain management by providing discounts of up to $45 \%$ on flood insurance premiums for residents of participating communities. However, there are some problems with NFIP, including increasing debt, out-of-date information on flood maps, and the encouragement of new developments in floodplains. Huber (2012) states that "The NFIP insures approximately 5.6 million American homeowners and has \$1 trillion in assets. The premiums collected have not been sufficient to cover losses, resulting in a current debt to the United States. Treasury of more than $\$ 18$ billion”. He suggests adjusting premiums, improving flood mitigation measures, and preparing for the catastrophic risk of events like Hurricane Katrina (Huber 2012). In addition, out-of-date information on flood maps from FEMA affects which homeowners should purchase flood insurance. After Hurricane Sandy devastated New York City in 2012, New York City's report, A Stronger, More Resilient New York (2013), indicates that more than 50\% of all buildings in the area flooded by Hurricane Sandy were outside of FEMA's 100-year floodplain map created in 1983. Another criticism is that the effectiveness of the NFIP encouraged floodplain development and generated repetitive losses with high financial costs (Brody et al. 2009). Discounting insurance premiums by the CRS system makes it less expensive for people to live in a 100-year floodplain, resulting in development in the most vulnerable areas to flooding (Brody et al. 2007). Furthermore, the lack of public awareness of floods remains. In the case of Hurricane Sandy, less than 50 percent of residential buildings in the pre-Sandy 100-year floodplain had flood insurance (The City of New York 2013). Therefore, the effort of flood risk awareness and communication needs to be more emphasized. Non-engineering strategy such as NFIP, provide financial incentives for homeowners to reduce their flood risks and losses. However, the incentive shouldn't increase the vulnerability of people living close to or in floodplains. Besides, flood insurance transfers risk and reduces homeowners' losses, but flooding risk doesn't disappear or ebb. Hence, another non-engineering strategy, land-use or environmental planning, becomes necessary to reduce vulnerability.

\subsection{Land-use and Environmental Planning Model}

In the last century, flood risk reduction around the world primarily relied on engineering structures. Historic floods indicate that flood resilience can not be achieved completely without land-use and environmental planning strategies. However, conventional land-use planning often ignores the hazard characteristics of the land. How to enhance risk-based land-use and environmental planning will play a role in reducing flood risk. Jha et al. (2013) emphasize "risk-based land-use planning", explaining that "integrating the risk-based land use planning approach into urban governance and process can help to make more sustainable ways to increase resilience" (Jha et al. 2013). However, flood risk reduction or water resource management is often not integrated with land-use planning. Woltjer and $\mathrm{Al}$ (2007) indicate "most water management decisions in the Netherlands are made without reference to spatial planning". They suggest the water impact assessment in municipal land use plans is a strategy for linking water management and spatial planning. The Luino et al. (2012) case study in Italy also indicates that "flood-prone areas have been conducted for years without considering land use" and that "urban development has not been controlled by careful land management that considers natural threats". Nonetheless, after the failure of the engineering strategy and the costly price of not integrating water management and land-use planning in reducing flood risks, the land-use and environmental planning strategy becomes more imminent. Hawkins (2013) stresses the importance of the connection between local comprehensive planning and disaster management. When members of organizations become more engaged in exchanging information among organizations within their planning network, they are more likely to have a favorable perception of the comprehensive plan in improving disaster resilience (Hawkins 2013).

In Europe, the European Commission's Flood Directive (2007) indicates that "flood risk management plans should focus on prevention, protection and preparedness, with a view to giving rivers more space". The European Commission's Water Framework Directive promotes a "river-basin approach" and "refers explicitly to interrelations between water management and land use". Flood management in Europe is shifting from building dikes (separating water from land use) to "space for the river" by land-use and environmental planning. Moreover, expanding the floodplain is a necessary planning strategy. Bye and Horner (1998) indicate "the defense flooding of a 1 in 100 year severity may only provide defense against floods of up to 1 in 30 year severity in the future" because of frequent extreme conditions and the global warming scenario. Woltjer and Al (2007) suggest "enlarging the floodplain area available to accommodate Rhine River waters during floods by converting land from urban and agricultural uses to a land use called water area." Hence, floodplains needs to be adjusted and expanded to accommodate water, and then reduce flood risk. Damages would also be decreased by allowing less development density in or adjacent to floodplains.

In addition to planning more space for the river to increase urban flood resilience, research indicates that wetland planning, polder and retention areas, and permeable surface design matter in reducing flood risks. The disappearance of 
wetlands and the increase in impervious surfaces due to rapid urbanization have increased the runoff and flood risk around the world. Research indicates that wetlands have a significant effect on flood risk reduction, and explains that basins with 5\% lake and wetland area may have $40 \%$ to $60 \%$ lower flood peaks than comparable basins without such hydrologic features (Novitski 1985). Brody et al. (2007) also studied the relationship of alteration of naturally occurring wetlands and flood damage through analyzing 383 flood events across 54 coastal counties in Florida from 1997 to 2001, and found that the alteration of naturally occurring wetlands significantly increases the property damage caused by floods. They also found that " $56 \%$ of all wetland alteration permits in research samples were located in 100 -year floodplains" (Brody et al. 2007). This means more wetlands were converted into new developments in floodplains in Florida. The disappearance of a large amount of wetlands as well as the occurrence of new developments in floodplains cause a higher vulnerability to floods. Brody and Gunn (2013) note that the percent of wetland loss matters in floods after examining environmental factors contributing to resilience along the Gulf of Mexico coast. Another example was Hurricane Katrina, as Dean (2006) indicates that the wetlands east of the Mississippi River lost $25 \%$ of their land area, but after Katrina, people finally understood the value of wetlands as a form of protection from hurricanes. Costanza et al. (2008) studied 34 major hurricanes in the U.S.A. since 1980, and found that "coastal wetlands reduce the damaging effects of hurricanes on coastal communities". They estimated that a loss of 1 hectare of wetland corresponded to an average $\$ 33,000$ increase in storm damage. Costanza et al. (2008) describe the coastal wetlands function as "horizontal levees for storm protection", and their restoration and preservation is an extremely cost-effective strategy (Costanza et al. 2008).

Polder systems and retention area planning also can reduce flood risks. Engkagul's Thailand case study indicates that planning for polder systems and retention areas would help reduce flood risk in larger areas (Engkagul 1993). Further, it is estimated that a 10-20\% increase of impervious surface within a drainage basin corresponds to doubling the runoff (Arnold and Gibbons 1996). The impermeable surface causes higher flood risk because of the increased runoff. Reducing the impervious surface would reduce flood risks. Therefore, land-use and environmental planning concentrating on wetland areas, water retention areas, and permeable surface design will provide a strategy for reducing flood risks. Woltjer and $\mathrm{Al}$ (2007) suggest a 10\% area in land use plans be for measures such as ponds and streams for emergency conveyance and storage of rain water, and permeable surfaces and grass-covered roofs to hold rain and allow soil infiltration.

Some case studies indicate that a significant flood risk comes from drainage flooding. Notable is the London case study. The Great London Authority (2002) evaluated London flood risks and identified three main types of flood risk: tidal, river, and drainage flooding. The result shows that "the most immediate and significant flood risk to London comes from drainage flooding" (Great London Authority 2002). Hence, integrating drainage systems with land-use planning provides another planning strategy to create robust flood resilience. In the United Kingdom, the Environment Agency (EA) is actively promoting the use of sustainable urban drainage systems (SUDS) to reduce levels of surface runoff. As Swan (2010) indicates "the SUDS approach, including green roofs, soak-aways, swales, infiltration basins and ponds, is intended to replace and/or augment an existing (combined or separate) drainage system within a developed catchment" (Swan 2010). The use of SUDS within a 'planning-based' approach, seeks to progressively impose green-field runoff restrictions to all new planning proposals (Swan 2010). Hence, SUDS can reduce the flood risk through retaining the flood volume temporarily and releasing it slowly at a lower flow-rate (Butler and Davies 2011). Howe and White (2010) also indicate that SUDS can help to attenuate water flow and prevent surface run-off, which can reduce flood risk. Swan (2010) stresses that urban planning has a key role to play in delivering more integrated and sustainable urban drainage systems in further urban regeneration over the next 50 years. He suggests that urban planning progressively retrofitting sustainable drainage to existing urban catchments needs to be more widely recognized. This will result in the reduction of flood risks and damages.

Another land-use and environmental planning policy, urban growth management, directing developments and populations away from floodplains, could reduce flood risks and damages. The United States case study in Florida indicates that urban growth management is an appropriate policy to reduce damages from hurricane flooding. Chapin et al. (2006) indicate that one of the main concerns of Florida's Growth Management Act in 1985 was to reduce damages from hurricane flooding. Since 1990, comprehensive plans require coastal communities to include policies that limit development in and direct populations away from coastal high hazard areas (CHHAs). Chapin et al. (2006) indicate "the more stringent policies for directing population concentrations away from CHHAs were associated with lower post-plan growth rates and growth densities". Hence, urban growth management to directing development away from floodplains and reducing its growth rate or density could provide a good strategy to reduce flood risks and vulnerability.

\subsection{Retreat and Evacuation Planning Model}

Some research of urban resilience stresses retreat and evacuation to reduce flood damage and its impact. A strategic retreat from hazardous coastal areas and alternatives, such as voluntary property buyouts, relocations, and land swaps 
for less risky areas should be explored to reduce flood risks and damages (Stein et al. 2000). Deyle and Butler (2013) also suggest a retreat model for flood risk reduction. Some strategies such as prohibiting development as well as the transfer of development rights (TDR), land acquisition, and down-zoning can be implemented. Additionally, an efficient evacuation plan is needed to reduce damages once severe floods do come. However, Kolen et al. (2010) indicate that one major issue is people's ability and willingness to evacuate. A plan needs to address the issue of people who do not or can not evacuate the area. In the U.S.A.'s case after Hurricane Katrina, it has been estimated that between 100,000 and 300,000 people did not or could not be evacuated from New Orleans. A large number of them were the city's poor populations, with 112,000 people not having access to personal vehicles (Wolshon 2006). Hence, helping the urban poor to evacuate demands the cooperation of government and non-profit organizations. Another factor is traffic capacity. Traffic management reduces the time required for evacuation. A Netherlands case study shows that "at least $20 \%$ of the people are still in the flooding area after 24 hours" (Kolen et al. 2010). Insufficient traffic capacity prevents the evacuation goal of 24 hours for coastal areas. In the U.S.A.'s experience after Hurricane Katrina, transportation infrastructure in New Orleans wasn't designed to accommodate the evacuation-level demand, and the traffic exit capacity is roughly $67 \%$, meaning that if the evacuation goes smoothly, the roads outside of New Orleans will only be able to take two-thirds of the people in 24 hours (Wolshon 2006). One-third of the people are in flooding areas. Hence, efficient traffic management becomes an important part of retreat and evacuation planning to reduce flood damage.

\section{Concluding Remarks}

The number of climate-related disasters, floods and storms, has soared significantly around the world since the 1980s. Urban resilience to flooding is gaining influence. Strengthening urban resilience also helps to achieve sustainability. Urban resilience planning concentrates mostly on the adaptive strategies. The more adaptive urban systems, the more resilient a city is. International policies regarding urban flood resilience are: United Nations' Post-2015 Framework for Disaster Risk Reduction (HFA), Sustainable Development Goals (SDGs), and Intergovernmental Panel on Climate Change (IPCC) report on Climate Change. These policies have provoked cities to play a proactive role in applying land-use and environmental planning strategies for disaster resilience. In general, there are four models around the world are primarily adopted for urban flood resilience: the engineering/structure model, the non-engineering/non-structure model, the land-use and environmental planning model, and the retreat planning model. In the engineering model, United States' costly structural projects for controlling water were completed mostly by the U.S. Army Corps of Engineers. However, flood control structures can not reduce the increased annual flood damage of $\$ 4$ billion in United States. In the Netherlands, the engineering model to reduce flood risk creates a flood control paradox, resulting in more intensive land use and higher vulnerability. In the non-engineering model, financial incentives and flood insurance are major strategies, moving housing away from vulnerable areas. In the land-use and environmental planning model, it has become more imminent after the failure of the engineering strategy and the costly price of not integrating water management and land-use planning in reducing flood risks. Planning more space for the river, wetland planning, polder and retention areas, and permeable surface design to increase urban flood resilience do matter in reducing flood risks. The United Kingdom is promoting sustainable urban drainage systems since a significant flood risk comes from drainage flooding. Additionally, the policy of urban growth management, directing developments and populations away from floodplains, could reduce flood risks and damages. In the retreat planning model, urban resilience stresses retreat and evacuation to reduce flood damage and its impact. These four models of urban flood resilience are not independently adopted. On the contrary, the combination of these four models helps to achieve urban resilience to flooding.

\section{Acknowledgments}

This study is part of Yu-Shou Su's Ph.D. Dissertation at University of Pennsylvania, United States. A special gratitude to Dr. Eugénie L. Birch, Chair of the Graduate Group in City and Regional Planning at University of Pennsylvania, for her professionalism, enthusiasm, and encouragement that have helped this research.

\section{References}

Aerts, J., Major, D. C., Bowman, M. J., Dircke, P., \& Marfai, M. A. (2009). Connecting Delta Cities. VU University Press, Amsterdam, Netherlands.

Amiri, A. S. F., Seidi, M., \& Riasi, A. (2012). Identifying the Barriers to Iran's Saffron Export by Using Porter's Diamond Model. International Journal of Marketing Studies, 4(5), 129-138.

Arnold, C. L., Jr., \& Gibbons, C. J. (1996). Impervious surface cover- age: The emergence of a key environmental indicator. Journal of the American Planning Association, 62(2), 243-258. http://dx.doi.org/10.1080/01944369608975688

Association of Bay Area Governments. (2013). Regional Resilience Initiative: Policy Agenda for Recovery 
Berke, P. R., Lyles, W., \& Smith, G. (2014). Impacts of Federal and State Hazard Mitigation Policies on Local Land Use Policy, Journal of Planning Education and Research 2014, 34(1) 60-76. http://dx.doi.org/10.1177/0739456X13517004

Birch, E. L., \& Wachter, S. M. (ed.). (2006). Rebuilding Urban Places after Disaster: Lessons from Hurricane Katrina. University of Pennsylvania Press.

Brody, S. D., \& Gunn, J. R. (2013). Examining Environmental Factors Contributing to Community Resilience along the Gulf of Mexico Coast. Disaster Resilience: Interdisciplinary Perspectives, Routledge, NY.

Brody, S. D., Kang, J. E., \& Bernhardt, S. (2009). Identifying factors influencing flood mitigation at the local level in Texas and Florida: the role of organizational capacity, Nat. Hazards., (2010) 52, 167-184

Brody, S. D., Zahran, S., Maghelal, P., Grover, H., \& Highfield, W. E. (2007). The Rising Costs of Floods- Examining the Impact of Planning and Development Decisions on Property Damage in Florida. Journal of the American Planning Association, 73(3), 330-345. http://dx.doi.org/10.1080/01944360708977981

Burby, R. J., Nelson, A. C., \& Sanchez, T. W. (2006). The Problems of Containment and the Promise of Planning. Rebuilding Urban Places after Disaster: Lessons from Hurricane Katrina. University of Pennsylvania Press.

Butler, D., \& Davies, J. W. (2011) Urban Drainage, 3rd Edition, Spon Press, London.

Bye, P., \& Horner, M. (1998). Easter 1998 Floods-Final Assessment by the Independent Review Team, Report to the Board of the Environment Agency, September.

Campanella, T. J. (2006). Urban Resilience and the Recovery of New Orleans. Journal of the American Planning Association, Spring 2006, 72(2). http://dx.doi.org/10.1080/01944360608976734

Chapin, T., Deyle, R., \& Baker, J. (2006). Assessing the Effectiveness of Comprehensive Plans in Mitigating Exposure of Florida Coastal Communities to Hurricane Flooding. Policy Brief, 23, Florida State University

City of New York. (2013). PlaNYC: A Stronger, More Resilient New York. City of New York.

Costanza, R., Pe'rez-Maqueo, O., Martinez, M. L., Sutton, P., Anderson, S. J., \& Mulder, K. (2008). The Value of Coastal Wetlands for Hurricane Protection. A Journal of the Human Environment, 37(4), 241-248. http://dx.doi.org/10.1579/0044-7447(2008)37[241:TVOCWF]2.0.CO;2

Dean, R. G. (2006). The Bridge: New Orleans and the Wetlands of Southern Louisiana, National Academy of Engineering.

Deyle, R. E., \& Butler, W. H. (2013). Resilience Planning in the Face of Uncertainty: Adapting to Climate Change Effects on Coastal Hazards. Disaster Resilience: Interdisciplinary Perspectives, Routledge, NY

Engkagul, S. (1993). Flooding Features in Bangkok and Vicinity: Geographical Approach, Geo Journal, 31(4), (December 1993), 335-338.

Environment Agency. (2001). Lessons learned Autumn 2000 floods.

Environment Agency. (2012). Managing flood risk through London and the Thames estuary, Thames Estuary 2100 (TE2100) Plan.

European Commission. (2007). Directive 2007/60/EC of the European Parliament and of the Council of 23 October 2007 on the assessment and management of flood risks, Official Journal of the European Union, Retrieved from http://ec.europa.eu/environment/water/flood_risk/key_docs.htm\#Directive

European Commission. (2012). Report from the Commission to the European Parliament and the Council on the Implementation of the Water Framework Directive (2000/60/EC) River Basin Management Plans.

Federal Emergency Management Agency. (2013). Hazus-MH: Flood User Manual. http://www.fema.gov/media-library-data/20130726-1820-25045-8814/hzmh2_1_fl_um.pdf

Fiksel, J. (2006). Sustainability and resilience: toward a systems approach. Sustainability: Science Practice and Policy, 2(2), 14-21.

Greater London Authority. (2002). Flooding in London A London Assembly Scrutiny Report November 2002.

Greater London Authority. (2009). London Regional Flood Risk Appraisal

Greater London Authority. (2012). London Strategic Flood Framework., Retrieved from http://www.london.gov.uk/sites/default/files/archives/london-prepared-London-Strategic-Flood-Framework-V2.pdf

Greater

London

Authority.

(2014).

Retrieved

from 
https://www.london.gov.uk/media/assembly-press-releases/2014/04/revive-rivers-to-reduce-flood-risk-in-london

Hawkins, C. V. (2013). Networks, Collaborative Planning, and Perceived Quality of Comprehensive Plans. Disaster Resilience: Interdisciplinary Perspectives, Routledge, NY

Howe, J., and White, I. (2010). Flooding- Are We Ignoring the Real Problem and Solution?, Regional Studies, 35:4, 368-370. http://dx.doi.org/10.1080/713693820

Huber, D. (2012). Fixing a Broken National Flood Insurance Program: Risk and Potential Reforms, Center for Climate and Energy Solutions (C2ES formerly the Pew Center on Global Climate Change), Retrieved from http://www.c2es.org/docUploads/flood-insurance-brief.pdf

Hurricane Sandy Rebuilding Task Force. (2013). Hurricane Sandy Rebuilding Strategy: Stronger Communities, A Resilient Region.

IPCC. (2007). "Climate Change 2007: Synthesis Report. Contribution of Working Groups I, II and III to the Fourth Assessment Report”, Retrieved from http://www.ipcc.ch/pdf/assessment-report/ar4/syr/ar4_syr.pdf.

IPCC. (2014). Summary for Policymakers. IPCC Working Group III Contribution to AR5.

Jha, A. K., Miner, T. W., \& Stanton-Geddes, Z. (2013). Building Urban Resilience: Principles, Tools, and Practice. The World Bank. http://dx.doi.org/10.1596/978-0-8213-8865-5

Joint Research Centre of the European Commission. (2015). Index for Risk Management (INFORM): Concept and Methodology. Luxembourg: Publications Office of the European Union

Klinenberg, E., \& Ovink, H. (2013). The Quest for the Best Designs for a Post-Sandy World, Retrieved from http://www.citylab.com/design/2013/09/quest-best-designs-post-sandy-world/6838/

Kolen, B., Holterman, S., Zuilekom, K., Friso, K., \& Helsloot, I. (2010). If things do go wrong- influence of road capacity on mass evacuation in the event of extreme flooding in The Netherlands, http://www.hkv.nl/site/hkv/upload/publication/

Kunreuther, H., \& Michel-Kerjan, E. O. (2009). At war with the weather: managing large-scale risks in a new era of catastrophes. Massachusetts Institute of Technology. http://dx.doi.org/10.7551/mitpress/9780262012829.001.0001

Kunreuther, H., \& Roth, R. (1998). Paying the Price: The Status and Role of Insurance Against Natural Disasters in the United States. Washington, DC: Joseph Henry Press.

Lang, R. E. (2006). Measuring Katrina’s Impacts on the Gulf Megapolitan Area. Rebuilding Urban Places After Disaster: Lessons from Hurricane Katrina. University of Pennsylvania Press.

London Assembly Environment Committee. (2014). Flood Risks in London: Summary of Findings. Retrieved from https://www.london.gov.uk/sites/default/files/14-04-07-Flood\%20risk\%20slide\%20pack\%20-\%20FINAL.pdf

Luino, F., Turconi, L. , Petrea, C., \& Nigrelli, G. (2009). Uncorrected land-use planning highlighted by flooding- the Alba case study (Piedmont, Italy), Natural Hazards and Earth System Sciences, 12, 2329-2346, 2012, www.nat-hazards-earth-syst-sci.net/12/2329/2012/

Milman, A., \& Short, A. (2008). Incorporating resilience into sustainability indicators: An example for the urban water sector. Global Environmental Change, 18(4), 758-767.

Mitchell, J. K. (1999). Crucibles of Hazard: Mega-cities and Disasters in Transition. United Nations University Press

Mitchell, T., Guha-Sapir, D., Hall, J., Lovell, E., Muir-Wood, R., Norris, A., Scott, L., \& Wallemacq, P. (2014). Setting, Measuring and Monitoring Targets for Reducing Disaster Risk: Recommendations for Post-2015 International Policy Frameworks. London: ODI.

Novitski, R. P. (1985). The effects of lakes and wetlands on flood flows and base flows in selected northern and eastern states. Proceedings of the Conference on Wetlands of the Chesapeake (pp. 143-154). Easton, MD: Environmental Law Institute.

OECD. (2014). OECD Reviews of Risk Management Policies: Seine Basin, Ile-de-France, 2014 Resilience to Major Floods

OECD. (2014). Water Governance in the Netherlands: Fit for the Future? OECD Studies on Water, OECD Publishing. http://dx.doi.org/10.1787/9789264102637-en

OECD. Poverty and Climate Change Reducing the Vulnerability of the Poor through Adaptation, http://www.oecd.org/env/cc/2502872.pdf

Olshansky, R. B. (2001). Land Use Planning for Seismic Safety: The Los Angeles County Experience, 1971-1994, 
Journal of the American Planning Association, 67(2). http://dx.doi.org/10.1080/01944360108976227

Olshansky, R. B. (2006). Longer View: Planning After Hurricane Katrina, Journal of the American Planning Association, 72(2). http://dx.doi.org/10.1080/01944360608976735

Olshansky, R. B. (2009). Planning for natural hazards. Local planning: contemporary principles and practice. ICMA.

Olshansky, R. B., Johnson, L. A., Horne, J., \& Nee, B. (2008). Longer View: Planning for the Rebuilding of New Orleans, Journal of the American Planning Association, 74(3). http://dx.doi.org/10.1080/01944360802140835

Penning-Rowsell, E. C., \& Handmer, J. W. (1988). Flood Hazard Management in Britain- A Changing Scene, The Geographical Journal, 154(2), 209-220. http://dx.doi.org/10.2307/633847

Powers, M. P. (2006). A Matter of Choice: Historical Lessons for Disaster Recovery. Hartman, Chester and Squires, Gregory D. (Eds). There Is No Such Thing As A Natural Disaster. Routledge New York and London.

Riasi, A., \& Amiri Aghdaie, S. F. (2013). Effects of a Hypothetical Iranian Accession to the World Trade Organization on Iran's Flower Industry. Consilience: The Journal of Sustainable Development, 10(1), 99-110.

Riasi, A., \& Pourmiri, S. (2015). Effects of online marketing on Iranian ecotourism industry: Economic, sociological, and cultural aspects. Management Science Letters, 5(10), 915-926.

Riasi, A., \& Pourmiri, S. (2016). Examples of Unsustainable Tourism in Middle East. Environmental Management and Sustainable Development, 5(1), 69-85.

Rosic, H., Bauer, G., \& Jammernegg, W. (2009). A framework for economic and environmental sustainability and resilience of supply chains. In Rapid modelling for increasing competitiveness (pp. 91-104). Springer London.

Sinh, B. T., Bhat, G. K., Moench, M., \& Gawler, S. (2012). Building Resilience in Asian Cities. Otto-Zimmermann (ed.). 2012. Resilient Cities 2: Cities and Adaptation to Climate Change-Proceedings of the Global Forum 2011. Springer: Dordrecht, Heidelberg, New York, London. http://dx.doi.org/10.1007/978-94-007-4223-9_24

Stecko, S., \& Barber, N. (2007). Exposing Vulnerabilities: Monsoon Floods in Mumbai, India: Case study prepared for Revisiting Urban Planning: Global Report on Human Settlements 2007 http://www.unhabitat.org/grhs/2007

Stein, J., Moreno, P., Conrad, D., \& Ellis, S. (2000). Troubled waters: Congress, the Corps of Engineers, and wasteful water projects. Washington, DC: Taxpayers for Common Sense and National Wildlife Federation.

The British Geological Survey. Retrieved from http://www.bgs.ac.uk/suds/

The City of New York. (2013). PlaNYC: A Stronger, More Resilient New York

The Minister of Transport, Public Works and Water Management (MTPWM). (2005). Flood Risks and Safety in the Netherlands. http://ec.europa.eu/ourcoast/download.cfm?fileID=1058

The Minister of Transport, Public Works and Water Management (MTPWM). (2007). Room for the River Plan. http://www.ruimtevoorderivier.nl/english/room-for-the-river-programme/

The Ministry of Transport, Public Works and Water Management (MTPWM). (2008). Flood risk: Understanding concepts. Ministry of Transport, Directorate-General of Water Affairs, Netherlands.

The National Academy of Sciences. (2012). Disaster Resilience: A National Imperative, The National Academies Press: Washington, D.C.

The National Academy of Sciences. (2013). Levees and the National Flood Insurance Program: Improving Policies and Practices, The National Academies Press: Washington, D.C.

The NYS 2100 Commission. (2013). Recommendations to Improve the Strength and Resilience of the Empire State's Infrastructure

The World Bank. (2001). World Development Report 2000/2001: Attacking Poverty. New York: Oxford University Press

The World Bank. (2013). Building Urban Resilience: Principles, Tools, and Practice.

The World Bank. (2013). Turn Down Heat the Climate Extremes, Regional Impacts, and the Case for Resilience.

Thompson, J. Phillip. (2009). Response to "Post-Disaster Planning in New Orleans, Journal of Planning Education and Research March 2009.

United Nations International Strategy for Disaster Reduction (UNISDR). (2005). Hyogo Framework for Action 2005-2015: Building the Resilience of Nations and Communities to Disasters.

United Nations International Strategy for Disaster Reduction (UNISDR). (2013). Making Cities Resilient: Summary for 
Policymakers. United Nations.

United Nations International Strategy for Disaster Reduction (UNISDR). (2012) ANNUAL REPORT 2011.

United Nations International Strategy for Disaster Reduction (UNISDR). (2015). World Conference Adopts New International Framework for Disaster Risk Reduction after Marathon Negotiations, Press release 18 March 2015UNISDR 2015/19

United Nations. (2012). World Urbanization Prospects, the 2011 Revision: Highlights. United Nations Department of Economic and Social Affairs, Population Division. New York

United Nations. (2013). The Global Assessment Report on Disaster Risk Reduction (GAR) 2013.

United Nations. (2014). Post-2015 framework for disaster risk reduction: Zero draft submitted by the co-Chairs of the Preparatory Committee. Third United Nations World Conference on Disaster Risk Reduction Preparatory Committee Second session, Geneva, 17-18 November 2014.

United Nations. (2014). Suggested elements for the post-2015 framework for disaster risk reduction. Third United Nations World Conference on Disaster Risk Reduction Preparatory Committee First session, Geneva, 14-15 July 2014

United Nations. (2015). The Global Assessment Report on Disaster Risk Reduction (GAR) 2015.

Vale, L. J., \& Campanella, T. J. (2005). The Resilient City: How Modern Cities Recover from Disaster. Oxford University Press.

Wahlström, M. (2015). How can the world better prepare for natural disasters? World Economic Forum, Agenda, March 122015 https://agenda.weforum.org/2015/03/how-can-the-world-better-prepare-for-natural-disasters/

White, I. (2010). Water and the City: Risk, Resilience and Planning for a Sustainable Future. London, Routledge.

White, M. D., \& Greer, K. A. (2006). The effects of watershed urbanization on the stream hydrology and riparian vegetation of Los Peñasquitos Creek, California. Landscape and Urban Planning, 74 (2), $125-138$. http://dx.doi.org/10.1016/j.landurbplan.2004.11.015

Wiering, M., \& Immink, I. (2006). When water management meets spatial planning: a policy-arrangements perspective. Environment and Planning C: Government and Policy 2006, 24, 423-438. http://dx.doi.org/10.1068/c0417j

Wolshon, B. (2006). The Bridge: Evacuation Planning and Engineering for Hurricane Katrina, National Academy of Engineering.

Woltjer, J., \& Al, N. (2007). Integrating Water Management and Spatial Planning, Journal of the American Planning Association, 73(2), Spring 2007.

\footnotetext{
Notes

Note 1. HFA (Framework for Action 2005-2015): In January 2005, 168 Governments adopted a 10-year plan to make the world safer from natural hazards at the World Conference on Disaster Reduction, held in Kobe, Hyogo, Japan.

Note 2. By 2050, the United Nations expects $80 \%$ of the world's population living in urban areas. Resilience planning needs to be the focus for cities.

Note 3. There are 3,455 floods and 2,689 storms in 1980-2011, an average of approximately 200 floods and storms annually over the last three decades.

Note 4. According to U.K. Environment Agency (one of the thirty-six agencies belong to the U.K. Cabinet's Department for Environment Food \& Rural Affairs), Thames Bar spans 520 meters across the River, and it protects 125 square kilometers of central London from flooding. Main gates stand as high as a 5- story building. The construction cost is approximately $\$ 796$ million (535 million GBP) in 1982. This cost is estimated at $\$ 2$ billion (1.4 billion GBP) at today's prices.

Note 5. According to U.S. Federal Emergency Management Agency (FEMA), more recent flood map products include digital flood insurance rate maps (FIRMs), which are created using digital methods and can be incorporated into a community's Geographic Information System (GIS).

Note 6. The European Flood Directive (FD) was proposed by the European Commission in 2006 to reduce and manage the flood risk. Note 7. The European Water Framework Directive (WFD) was established in 2000 as a policy platform in both quantitative water issues (cross-border flood management, water-supply management, and groundwater control) and qualitative aspects.
}

\section{(cc) BY}

This work is licensed under a Creative Commons Attribution 3.0 License. 